\title{
GROWTH AND LEVELS OF N, P AND K IN ROOTSTOCKS OF TAMARIND TREES USING ORGANIC SUBSTRATES AND DOSES OF PHOSPHORUS ${ }^{1}$
}

\author{
EDUARDO CASTRO PEREIRA ${ }^{2 *}$, JOSÉ MARIA DA COSTA ${ }^{2}$, FRANCISCO MICKAEL DE MEDEIROS \\ CÂMARA ${ }^{2}$, WAGNER CÉSAR DE FARIAS ${ }^{2}$, VANDER MENDONÇA ${ }^{3}$
}

\begin{abstract}
The aim of this study was to evaluate different organic substrates and phosphorus doses on the growth and leaf content of nitrogen, phosphorus and potassium in rootstocks of Tamarindus indica L. The experiment was performed in a greenhouse nursery located on the campus of the Universidade Federal Rural do Semi-Árido (UFERSA), from March to October 2013. The treatments consisted of three organic sources at a concentration of $40 \%(\mathrm{v} / \mathrm{v})$ (bovine manure, goat manure and a commercial organic compound) and four doses of simple superphosphate $\left(0,0 \mathrm{~kg} \mathrm{~m}^{-3}, 2.5 \mathrm{~kg} \mathrm{~m}^{-3}, 5.0 \mathrm{~kg} \mathrm{~m}^{-3}\right.$ and $\left.7.5 \mathrm{~kg} \mathrm{~m}^{-3}\right)$. The experiment was conducted in a randomized block design (RBD), with 12 treatments (substrates), four replications and 10 plants per plot, totaling 480 plants. The goat manure and the organic compound were the most suitable treatments for the production of rootstocks of the tamarind tree. The maximum dose of $7.5 \mathrm{~g} \mathrm{~kg}^{-1}$ of simple superphosphate caused the highest levels of phosphorus and potassium in the dry mass of shoots. The nutrients in the dry matter of shoots accumulated in the following order: $\mathrm{N}>\mathrm{K}>\mathrm{P}$.
\end{abstract}

Keywords: Tamarindus indica L., Floriculture. Animal manure. Mineral nutrition.

\section{CRESCIMENTO E TEORES DE N, P E K EM PORTAENXERTOS DE TAMARINDEIRO UTILIZANDO SUBSTRATOS ORGÂNICOS E DOSES DE FÓSFORO}

\begin{abstract}
RESUMO - Com o objetivo de avaliar diferentes substratos orgânicos, doses de fósforo no crescimento e teor foliar de nitrogênio, fósforo e potássio em portaenxertos de Tamarindus indica L., conduziu-se um experimento em um viveiro telado localizado no campus da Universidade Federal Rural do Semi-Árido (UFERSA), no período de março a outubro de 2013. Os tratamentos constaram de: três fontes orgânicas na proporção de $40 \%$ v.v ${ }^{1}$, (esterco bovino, esterco caprino e um composto orgânico comercial) em quatro doses de superfosfato simples $\left(0,0 \mathrm{~kg} \mathrm{~m}^{-3}, 2,5 \mathrm{~kg} \mathrm{~m}^{-3}, 5,0 \mathrm{~kg} \mathrm{~m}^{-3}, 7,5 \mathrm{~kg} \mathrm{~m}^{-3}\right)$. O experimento foi conduzido em delineamento de blocos casualizados (DBC), com 12 tratamentos (substratos), quatro repetições e 10 plantas por parcela, perfazendo um total de 480 plantas. O esterco caprino e o composto orgânico foram os mais adequados para a produção de portaenxerto de tamarindeiro. A dose máxima de $7,5 \mathrm{~g} \mathrm{~kg}^{-1}$ de superfosfato simples proporcionou os maiores teores de fósforo e potássio na massa seca da parte aérea. $\mathrm{O}$ acúmulo de nutrientes na massa seca da parte aérea obedece a seguinte ordem: $\mathrm{N}>\mathrm{K}>\mathrm{P}$.
\end{abstract}

Palavras-chave: Tamarindus indica L.. Fruticultura. Esterco animal. Nutrição mineral.

\footnotetext{
*Corresponding author

${ }^{1}$ Received for publication in $07 / 29 / 2014$; Accepted in $11 / 18 / 2015$.

Part of the Master's Dissertation of the first author.

${ }^{2}$ Graduate Program in Plant Science, Universidade Federal Rural do Semi-Árido - UFERSA, Mossoró, RN, Brazil; edu_castro7@hotmail.com,jmc.atm@hotmail.com,mickaelmedeiros12@gmail.com, cesareaj@yahoo.com.br.

${ }^{3}$ Department of Plant Sciences (DCV), Universidade Federal Rural do Semi-Árido, Mossoró, RN, Brazil; vander@ufersa.edu.br.
} 


\section{INTRODUCTION}

Tamarind (Tamarindus indica L.), which originates from tropical Africa, is well acclimatized in Brazil, and is naturalized and found in various regions, and is considered to be a typical fruiting plant in the Northeast, but little technical information concerning its cultivation in this and other regions is available (PEREIRA et al., 2007).

The use of high-quality seedlings is essential for any cultivated plant, including the tamarind tree; therefore, to obtain quality seedlings, it is necessary to use substrates with physical, chemical and biological properties that are compatible with germination, in addition to the growth and mineral nutrition of the seedling. Furthermore, the quality of the substrate depends on the constituents and their proportions in the mixture composition (SILVA et al., 2001; NOGUEIRA et al., 2003).

For the composition of substrates, manures are often used because they have characteristics that are beneficial to improving the physico-chemical properties of the substrates and to stimulate microbial processes. For seedling production, plant growth is variable, depending on the species, sources and manure proportions (MORAIS et al., 2012).

Seedling nutrition is of the utmost importance in the field; however, despite knowledge concerning the influence and importance of nutrients on plant growth, it is necessary to establish proper doses to result in economically viable production and to maximize growth, as nutritional imbalances can harm the seedlings, by affecting their morphology, in addition to influencing survival and further development in the field (PAULA et al., 2010).

Among the nutrients required for seedling development, phosphorus $(\mathrm{P})$ is the most important, due to the low $\mathrm{P}$ content of tropical soils (LIMA et al., 2011; PRADO et al., 2005) and the high $\mathrm{P}$ demand by seedlings of perennial plants in their early growth stages (LIMA et al., 2011; NOVAIS; SMYTH, 1999).

The objective of this study was to evaluate the influence of different levels of phosphorus and organic sources on the contents of nitrogen $(\mathrm{N})$, phosphorus $(\mathrm{P})$ and potassium $(\mathrm{K})$ in the production of rootstocks of the tamarind trees.

\section{MATERIALS AND METHODS}

The study was conducted between March and October 2013, in the Federal Rural University of the Semi-Arid (UFERSA), East Campus, Mossoró-RN.

Seeds were used from healthy and ripe fruits, obtained from a healthy tamarind tree in the UFERSA orchard. Soon after seed harvest, the bark of all selected fruits was removed and these were subsequently immersed in a container with water for $12 \mathrm{~h}$ to facilitate the separation of the seeds from the pulp. The selection of the best seeds was performed manually, and small and damaged seeds were eliminated. The seeds were then sown in bags for the production of rootstocks (MENDONÇA et al., 2014).

The substrates used resulted from the mixture (Table 1) of three organic sources [Cattle Manure $(\mathrm{CM})$, goat manure (GM) and a commercial organic compound (eco fértil®) (CO)], plus the addition of different doses of simple superphosphate $\left(0.0 \mathrm{~kg} \mathrm{~m}^{-3}\right.$; $2.5 \mathrm{~kg} \mathrm{~m}^{-3}, 5.0 \mathrm{~kg} \mathrm{~m}^{-3}$ and $\left.7.5 \mathrm{~kg} \mathrm{~m}^{-3}\right)$. Black polyethylene bags were used as containers, with dimensions of $19 \times 25 \mathrm{~cm}$ and a volume of $3.200 \mathrm{~mL}$

Table 1. Combinations of the three organic sources and simple superphosphate doses for the composition of the substrates and the treatments used in the experiment.

\begin{tabular}{cc}
\hline TREATMENTS & COMBINATIONS \\
\hline Treatment 1 & $40 \%$ bovine manure $+0.0 \mathrm{~kg} \mathrm{~m}^{-3}$ superphosphate \\
Treatment 2 & $40 \%$ bovine manure $+2.5 \mathrm{~kg} \mathrm{~m}^{-3}$ superphosphate \\
Treatment 3 & $40 \%$ bovine manure $+5.0 \mathrm{~kg} \mathrm{~m}^{-3}$ superphosphate \\
Treatment 4 & $40 \%$ bovine manure $+7.5 \mathrm{~kg} \mathrm{~m}^{-3}$ superphosphate \\
Treatment 5 & $40 \%$ goat manure $+0.0 \mathrm{~kg} \mathrm{~m}^{-3}$ superphosphate \\
Treatment 6 & $40 \%$ goat manure $+2.5 \mathrm{~kg} \mathrm{~m}^{-3}$ superphosphate \\
Treatment 7 & $40 \%$ goat manure $+5.0 \mathrm{~kg} \mathrm{~m}^{-3}$ superphosphate \\
Treatment 8 & $40 \%$ goat manure $+7.5 \mathrm{~kg} \mathrm{~m}^{-3}$ superphosphate \\
Treatment 9 & $40 \%$ organic compound $+0.0 \mathrm{~kg} \mathrm{~m}^{-3}$ superphosphate \\
Treatment 10 & $40 \%$ organic compound $+2.5 \mathrm{~kg} \mathrm{~m}^{-3}$ superphosphate \\
Treatment 11 & $40 \%$ organic compound $+5.0 \mathrm{~kg} \mathrm{~m}^{-3}$ superphosphate \\
Treatment 12 & $40 \%$ organic compound $+7.5 \mathrm{~kg} \mathrm{~m}^{-3}$ superphosphate \\
\hline
\end{tabular}


Three tamarind seeds were sown per container, to ensure that consistent rootstocks were obtained, since the seeds have different degrees of dormancy and vigor. The seedlings were thinned about thirty days after sowing (DAS), leaving only one seedling per container. During the experiment, irrigation was performed daily, in the morning and late afternoon, via a micro-sprinkler system with a mean flow of $40 \mathrm{~L} . \mathrm{h}^{-1}$.

The experimental design was a completely randomized block in a $3 \times 4$ factorial scheme (three organic sources and four doses of simple superphosphate), with four replications. Each experimental unit was formed by ten rootstocks, totaling 480 plants.

During the experiment, samples of each substrate were removed and sent for analysis in the chemical analysis laboratory of UFERSA; the results are shown in Table 2.

Table 2. Chemical analysis of the substrates (treatments) used in the production of rootstocks of tamarind trees.

\begin{tabular}{rccccccc}
\hline Treatments & $\begin{array}{c}\mathrm{O} . \mathrm{M} \\
\mathrm{g} \mathrm{kg}^{-1}\end{array}$ & $\begin{array}{c}\mathrm{Ph} \\
\left(\mathrm{H}_{2} \mathrm{O}\right)\end{array}$ & $\mathrm{P}$ & $\mathrm{Ca}$ & $\begin{array}{c}\mathrm{Mg} \\
\left(\mathrm{mg} \mathrm{kg}^{-1}\right)\end{array}$ & $\mathrm{Na}$ & $\mathrm{K}$ \\
\hline $\mathrm{T} 1$ & 28.07 & 8.04 & 231.52 & 1422.84 & 12.15 & 603.86 & 1493.60 \\
$\mathrm{~T} 2$ & 21.26 & 8.03 & 270.11 & 1162.32 & 24.31 & 698.07 & 941.05 \\
$\mathrm{~T} 3$ & 14.96 & 8.15 & 178.79 & 1162.32 & 48.62 & 725.75 & 1731.63 \\
$\mathrm{~T} 4$ & 34.46 & 7.56 & 313.83 & 1482.96 & 48.62 & 685.12 & 1688.35 \\
T5 & 19.71 & 7.11 & 244.38 & 1102.2 & 243.12 & 159.72 & 827.70 \\
T6 & 40.37 & 7.37 & 245.67 & 861.72 & 170.18 & 197.56 & 995.90 \\
T7 & 13.31 & 7.01 & 235.38 & 1062.12 & 474.08 & 217.88 & 1147.38 \\
T8 & 18.57 & 8.00 & 694.51 & 1362.72 & 12.15 & 116.30 & 692.96 \\
T9 & 48.04 & 7.10 & 272.68 & 901.8 & 170.18 & 1416.46 & 385.65 \\
T10 & 49.65 & 7.69 & 243.10 & 1062.12 & 60.78 & 319.45 & 1709.99 \\
T11 & 19.17 & 7.63 & 227.67 & 2264.52 & 255.27 & 319.45 & 1645.07 \\
T12 & 21.39 & 7.20 & 226.38 & 1042.08 & 364.68 & 380.39 & 1666.71 \\
\hline
\end{tabular}

The experiment was stopped at 140 DAS, when the following destructive analyses for the morphological and nutritional characteristics were performed: the stem diameter of the rootstocks (SD), shoot length (SL), length of the root system (LRS), number of leaves (NL), dry mass of shoots (DMS), dry mass of the root system (DMR), total dry mass (TDM), and the content of N, P and K in the leaves.

The determination of the height and root length of the rootstocks was performed using a ruler graduated in centimeters. Height was obtained by measuring the distance between the neck and the apex of the rootstocks, and the length was obtained by measuring the distance from the neck to the apex of the root. A digital caliper was used to determine the stem diameter, with values expressed in $\mathrm{mm}$. The dry mass of roots and shoots was obtained after drying in a forced-air oven at $75^{\circ} \mathrm{C}$. The total dry mass was obtained form the sum of the dry mass of the shoot and root. To determine the concentration of $\mathrm{N}, \mathrm{P}, \mathrm{K}$ in the leaves, the recommendations of Tedesco et al. (1995) were followed.

The data were analysed using analysis of variance, the means were compared using the Tukey test at 5\% probability, and the quantitative data were subjected to regression analysis via the computer program SISVAR (FERREIRA, 2010). The adjustment of the response curves for the treatment factors was performed using the software Table Curve (JANDEL SCIENTIFIC, 1991).

\section{RESULTS AND DISCUSSION}

There was a significant interaction between the organic source and simple superphosphate dose only for the shoot and root dry mass and total dry mass. A significant effect of organic source and dose was observed for the characteristics of shoot length, shoot dry mass and total dry mass, whereas for root dry mass a significant difference was observed only for the organic source. The stem diameter, number of leaves and length of the root system was not significantly affected by any of the factors. A positive effect was observed for the interaction between the factors organic source and dose on the levels of the three nutrients tested, and for $\mathrm{P}$, no individual effect of the factors was observed.

The shoot length was greatest using goat manure and the commercial organic compound as an organic source, and values were statistically similar for both treatments, and were greater than those obtained with bovine manure (Table 3 ). 
Table 3. Mean shoot length (SL) of the rootstocks of tamarind trees, depending on various organic sources incorporated into the substrate.

\begin{tabular}{lc}
\hline & Evaluated Characteristics \\
Organic Sources & SL \\
\hline Bovine Manure & $59.86 \mathrm{~b}^{*}$ \\
Goat Manure & $62.24 \mathrm{ab}$ \\
Organic Compound & $64.90 \mathrm{a}$ \\
\hline LSD & 3.90 \\
CV $(\%)$ & 7.21 \\
\hline
\end{tabular}

Results similar to those obtained in this study were found by Mendonça et al. (2014), who studied different substrates and evaluated their effect on the rootstocks of tamarind, and confirmed that the substrates consisting of soil, bovine manure, goat manure and sheep manure mixtures promoted the greatest shoot lengths. However, Queiroz et al. (2011) tested the effect of different substrates on tamarind seedlings and found that organic sources led to taller rootstocks, which corroborates the results of this study, although the values in this study were greater.

The longest shoots at $63.86 \mathrm{~cm}$, were obtained with a dose of $2.50 \mathrm{~kg} \mathrm{~m}^{-3} \mathrm{P}$ (Figure 1), which differs from the data of Souza et al. (2007), who observed that a dose of $0.8 \mathrm{~kg} \mathrm{~m}^{-3} \mathrm{~N}$ with 10.0 $\mathrm{kg} \mathrm{m}^{-3} \mathrm{P}$ promoted the growth of tamarind rootstocks (shoot length; $33.72 \mathrm{~cm}$ ).

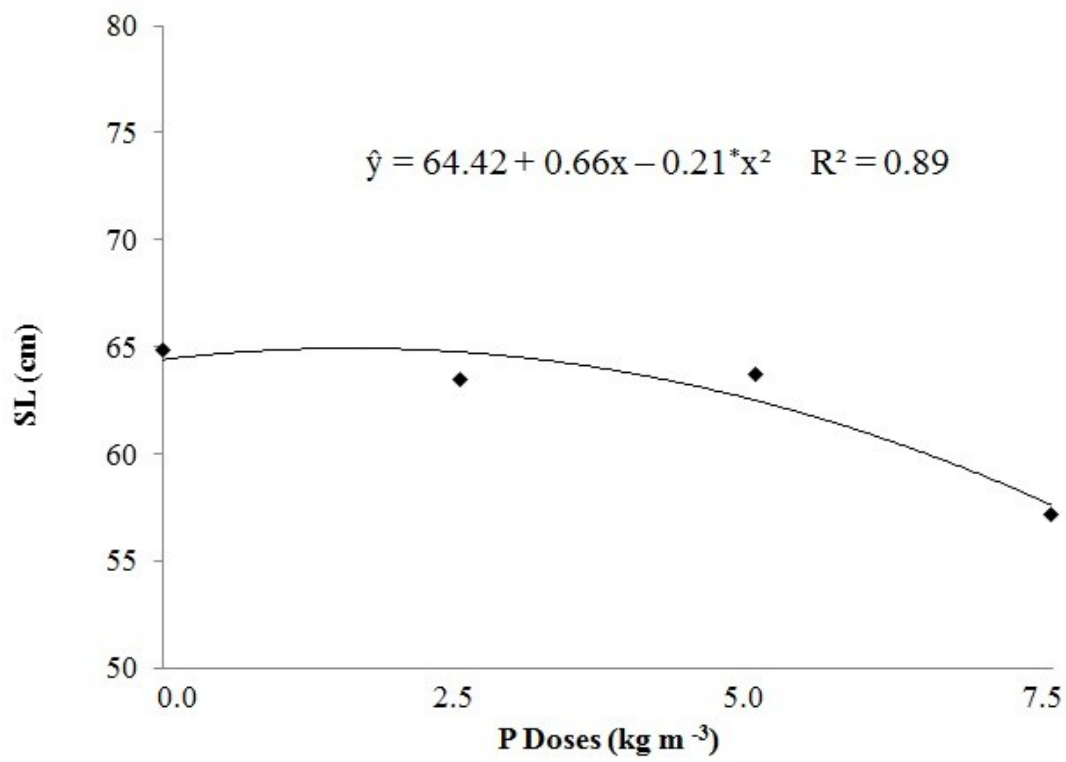

Figure 1. Shoot length (SL) of tamarind tree rootstocks, depending on different doses of phosphorus.

Using goat manure as an organic source, a dose of $1.03 \mathrm{~kg} \mathrm{~m}^{-3} \mathrm{P}$ resulted in the highest shoot dry mass of (39.11 $\left.\mathrm{g} \mathrm{plant}^{-1}\right)$, and with the organic compound source, a dose of $3.26 \mathrm{~kg} \mathrm{~m}^{-3} \mathrm{P}$ gave the maximum value of $35.96 \mathrm{~g} \mathrm{plant}^{-1}$ (Figure 2A). These results agree with those of Souza et al. (2007), who studied the effect of $\mathrm{N}$ and $\mathrm{P}$ doses on the growth of tamarind rootstocks in Lavras-MG, and found that the dry mass of shoots decreased as the $\mathrm{P}$ level increased. Some authors observed no significant effect of $\mathrm{P}$ supplementation in the substrate on root and shoot dry mass, as they already contained adequate levels of $\mathrm{P}$ for seedling growth (NIELSEN et al., 2001; DIAS et al., 2009).

When the levels of $\mathrm{P}$ within the sources were analyzed, the highest root dry mass (11.35 $\mathrm{g}$ plant $\left.^{-1}\right)$ was found in the absence of $\mathrm{P}$ fertilization, i.e., in the zero dose, with the equation being adjusted only for the goat manure source in the form of a linear equation (Figure 2B).

Different results were observed by Souza et al. (2007), who studied tamarind rootstocks and found an increase in the root dry matter yield at increased P levels, both in the presence and absence of N. Souza et al. (2003) analyzed the growth of seedlings of the soursop tree on a substrate with simple superphosphate and vermicompost and also found a statistically significant difference in the root dry mass with increasing $\mathrm{P}$ fertilization. 

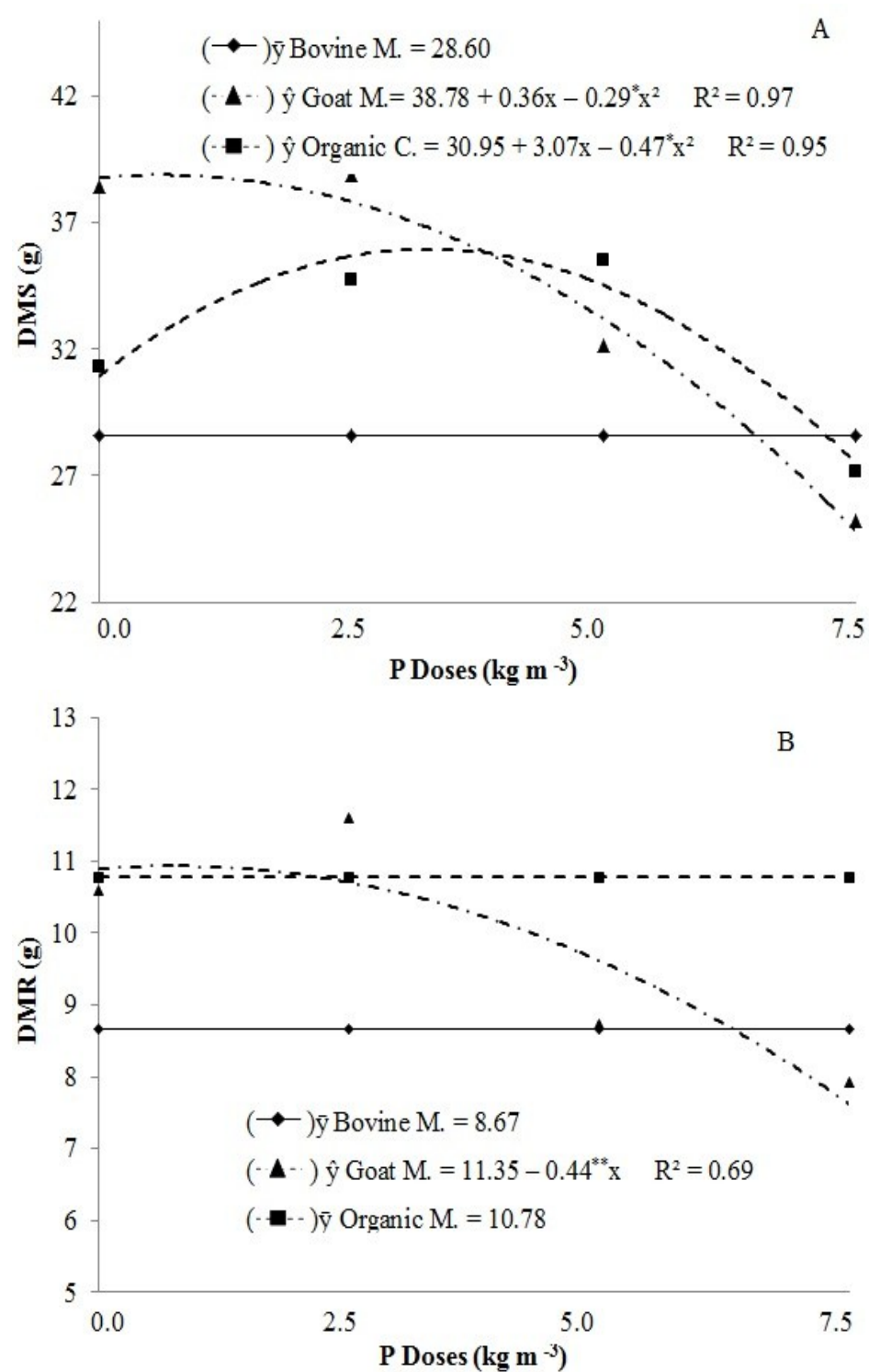

Figure 2. Effect of different doses of phosphorus and organic sources on the dry mass of shoots (DMS) (A) and dry mass of the root system (DMR) (B) of tamarind tree rootstocks.

For the variable total dry mass in Figure 3A, the calculated values were also adjusted using a linear equation, when goat manure was used as an organic source. The maximum value of $51.97 \mathrm{~g}$ plant ${ }^{-1}$ was obtained at a zero dose $\left(0.0 \mathrm{~kg} \mathrm{~m}^{-3}\right)$. This value was the only one for this variable among the three organic sources to adjust to a decreasing linear equation, using goat manure as a source. In the study of David (2008), a dose of $9.48 \mathrm{~kg} \mathrm{~m}^{-3}$ simple superphosphate influenced the total dry mass production of yellow passion-fruit seedlings. Mendonça et al. (2012) also obtained similar results to the previous author, and found a maximum total dry mass in seedlings of pitombeira at the maximum dose of two sources of $\mathrm{P}$ (mono-ammonium phosphate and simple superphosphate).

These previous results contradict those found in this study, which might be due to the presence of $\mathrm{P}$ in the organic sources added to the substrate (Table
2 ), resulting in a high concentration of the element and possibly resulting in a reduction in dry matter. Phosphorus can affect plant development, and act as a nutrient that stimulates the production of dry matter (DIAS et al., 2009). However, some authors have observed no significant effect of $\mathrm{P}$ supplementation to the substrate on the root and shoot dry mass, as the substrates already contained adequate $\mathrm{P}$ levels for seedling growth (NIELSEN et al., 2001; FERNANDEZ, 2002). This might be due to the different ability of cultures to extract available forms of $\mathrm{P}$ from the soil (LOPES, 1989).

When the levels of $\mathrm{P}$ in each organic source were analysed, according to Figure $3 \mathrm{~B}$, the maximum level of $\mathrm{N}$ for both bovine manure and for goat manure were observed in the zero dose, at 17.66 and $20.09 \mathrm{~g} \mathrm{~kg}^{-1}$, respectively, and the highest concentration for the organic compound source was observed at the maximum concentration of $\mathrm{P}$, with 
an absolute value of $20.05 \mathrm{~g} \mathrm{~kg}^{-1}$. The $\mathrm{N}$ concentration in the plant tissue of jatropha seedlings increased linearly in response to application rate of simple superphosphate to the substrate; the increase in the $\mathrm{N}$ content is probably due to the higher amount of roots and the importance of $\mathrm{P}$ for plant physiology, especially in processes that require energy, such as the absorption and assimilation of nitrogen (LIMA et al., 2011).
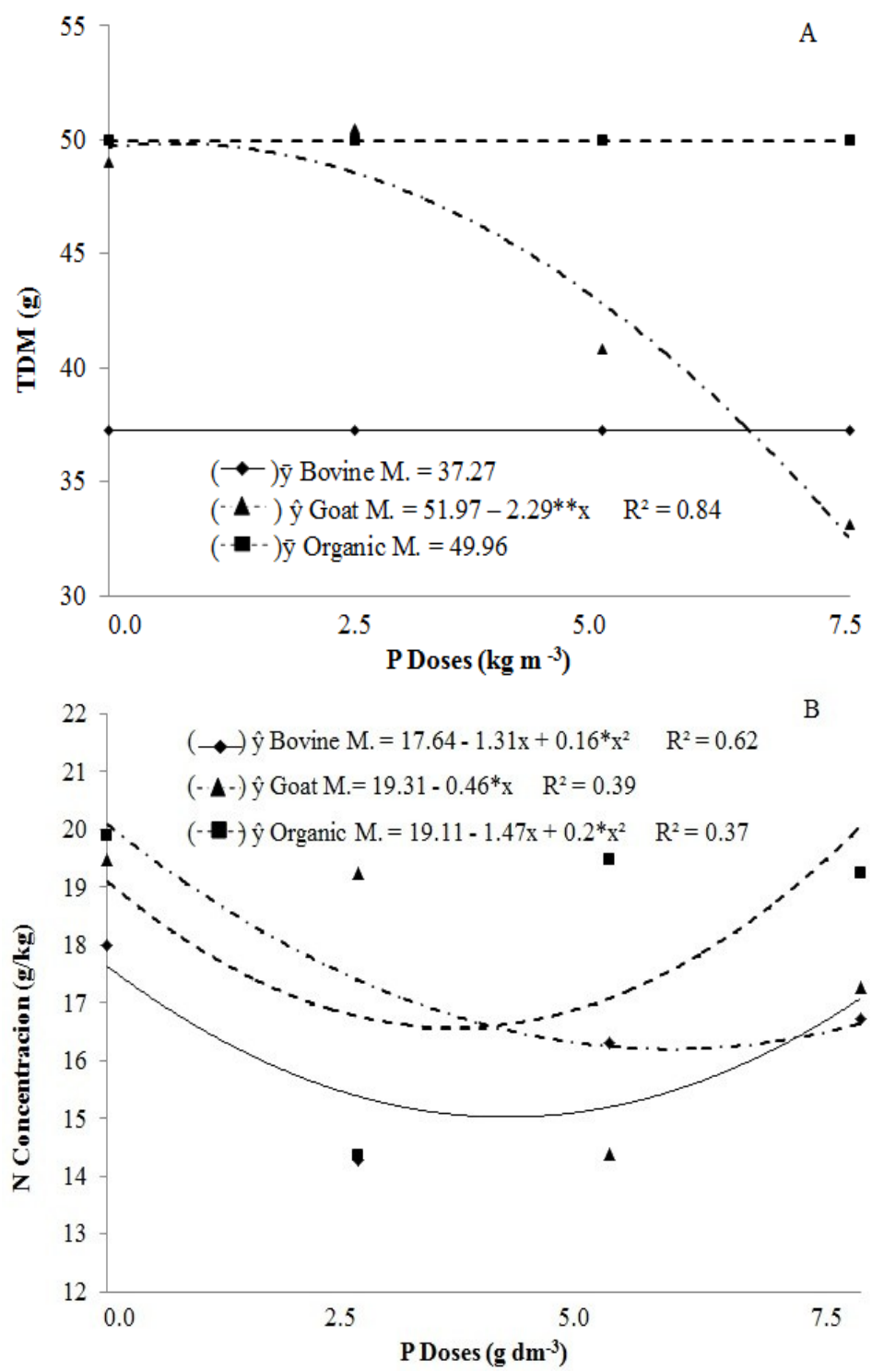

Figure 3. Effect of different doses of phosphorus and organic sources on the total dry mass (TDM) (A) and concentration of nitrogen $(\mathrm{N})$ on the dry mass of shoots $(\mathrm{B})$ of tamarind tree rootstocks.

The highest $\mathrm{P}$ content occurred at the maximum dose of $7.5 \mathrm{~kg} \mathrm{~m}^{-3}$ using bovine manure and goat manure as organic sources, with values of 6.88 and $6.72 \mathrm{~g} \mathrm{~kg}^{-1}$, respectively, and generating a quadratic and linear equation, respectively. When the commercial organic compound was used as an organic source, the values did not fit the equation, and the means were used (Figure 4A). The reduced plant growth on these substrates, together with the different organic sources led to the accumulation of $\mathrm{P}$ in the dry matter that was proportional to the concentration of $\mathrm{P}$, corroborating data from Lima et al. (2011), who observed a linear increase with higher doses of simple superphosphate for jatropha (Jatropha curcas) seedlings, which was a direct consequence of a higher $\mathrm{P}$ accumulation in the substrate. In general, perennial crops require a high $\mathrm{P}$ concentration in the substrate at the seedling stage, with a decreasing requirement with increasing age (NOVAIS; SMITY, 1999), which reinforces the importance of $\mathrm{P}$ addition to the substrate to generate tamarind seedlings. The highest concentrations of $\mathrm{K}$ were obtained at the maximum doses of $\mathrm{P}$ $\left(7.5 \mathrm{~kg} \mathrm{~m}^{-3}\right)$, and the highest concentration was $18.79 \mathrm{~g} \mathrm{~kg}^{-1}$, using the commercial organic compound as an organic source, a value that was 
$31.93 \%$ higher than that found using bovine manure as an organic source, which was $12.79 \mathrm{~g} \mathrm{~kg}^{-1} \mathrm{~K}$ in the shoot (Figure 4B). The K content can be interpreted by analyzing the concentration in the substrate (Table 2), which contained sufficient $\mathrm{K}$, although at a lower concentration than that found in the substrates consisting of a mixture of the two other organic sources (bovine manure and goat manure). Soares et al. (2007) observed that K was one of the nutrients that was absorbed the greatest by soursop seedlings fertilized with phosphate fertilizer, which was consistent with the findings of this study. Even at similar doses, differences in the accumulation of the macronutrients $\mathrm{N}, \mathrm{P}$ and $\mathrm{K}$ were observed, in contrast to the results of Pereira et al. (2010), who found similar concentrations for the different levels, in the composition of bed-of-chicken of the substrate.

The $\mathrm{K}$ content in jatropha seedlings increased significantly with the addition of lower doses of phosphate fertilizer, unlike at higher doses, which showed a lower effect on increasing the content of potassium in plant shoots (LIMA et al., 2011). However, Sousa et al. (2000) found no significant effect of the potassium concentration, depending on different doses of simple superphosphate. Overall, the mean accumulation of $\mathrm{N}, \mathrm{P}$ and $\mathrm{K}$ in the rootstocks of tamarind trees following treatment with the three organic sources showed the decreasing order: $17.39,15.19$ and $12.98 \mathrm{~g} \mathrm{~kg}^{-1}$, for $\mathrm{N}, \mathrm{K}$ and $\mathrm{P}$, respectively. Pereira et al (2010) identified a similar sequence of nutrients for tamarind seedlings in bedof-chicken proportions.
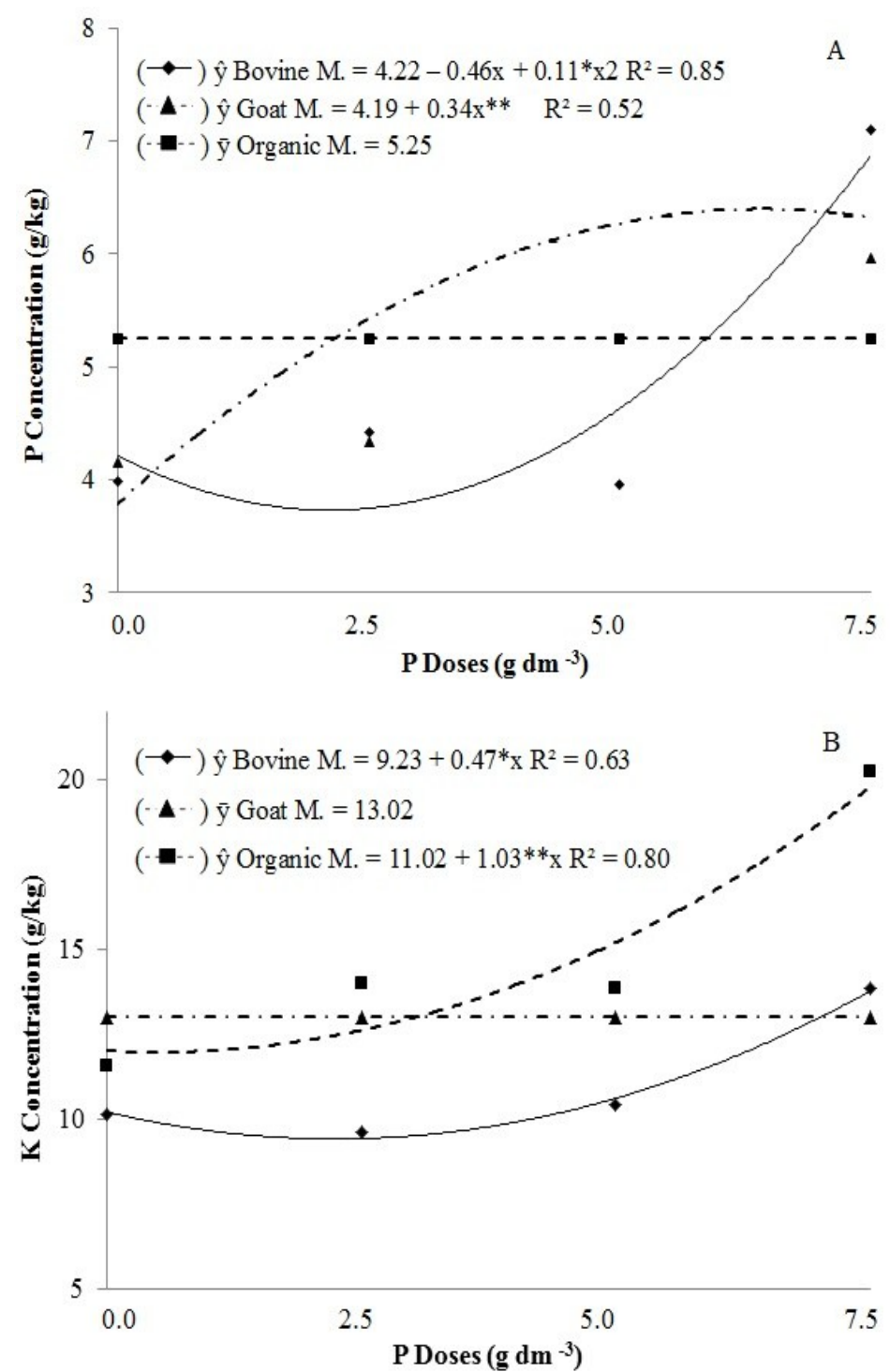

Figure 4. Effect of different doses of phosphorus and organic sources on the concentration of phosphorus in the shoot dry mass (A) and on the concentration of potassium in the shoot dry mass (B) of tamarind tree rootstocks. 


\section{CONCLUSION}

Goat manure and the commercial organic compound were the most suitable sources for the production of tamarind tree rootstocks. The maximum dose of $7.5 \mathrm{~g} \mathrm{~kg}^{-1}$ simple superphosphate led to the highest levels of $\mathrm{P}$ and $\mathrm{K}$ in the shoot dry mass. The accumulation of nutrients in shoot dry matter was in the order: $\mathrm{N}>\mathrm{K}>\mathrm{P}$.

\section{REFERENCES}

DAVID, M. A. et al. Efeito de doses de superfosfato simples e de matéria orgânica sobre o crescimento de mudas de maracujazeiro 'amarelo'. Pesquisa Agropecuária Tropical, Goiânia, v. 38, n. 3, p. 147 $152,2008$.

DIAS T. J. et al. Desenvolvimento e qualidade nutricional de mudas de mangabeiras cultivadas em substratos contendo fibra de coco e adubação fosfatada. Revista Brasileira Fruticultura, Jaboticabal, v. 31, n. 2, p. 512-523, 2009.

FERNANDEZ, J. R. C. Efeito de substratos, recipientes e adubação na formação de mudas de mangabeira (Hancornia speciosa Gomes). 2002. 95 p. Dissertação (Mestrado em Agronomia: Área de Concentração em Agricultura tropical) Universidade Federal do Mato Grosso, Cuiabá, 2002.

FERREIRA, D. F. Sisvar versão 5.3. Lavras-MG: UFLA, 2010.

JANDEL SCIENTIFIC. Table curve: curve fitting software. Corte Madera, CA: Jandel Scientific, p. 280, 1991.

LIMA, R. L. S. et al. Efeito da adubação fosfatada sobre o crescimento e teor de macronutrientes de mudas de pinhão manso. Revista Ciência Agronômica, Fortaleza, v. 42, n. 4, p. 950-956, 2011.

LOPES, A. S. Manual de fertilidade do solo. Piracicaba, SP: FUNDAÇÃO CARGILL, 1989. 177 p.

MENDONÇA, L. F. de M. et al. Fontes e doses de fósforo na produção de porta-enxertos de pitombeira. Revista Verde de Agroecologia e Desenvolvimento Sustentável, Pombal, v. 7, n. 4, p. 114-119, 2012.

MENDONÇA, V. et al. Avaliação de diferentes substratos na produção de porta enxertos de tamarindeiro. Revista Caatinga, Mossoró, v. 27, n. 1, p. 60-66, 2014.
MORAIS, F. A. et al. Fontes e proporções de esterco na composição de substratos para produção de mudas de jaqueira. Agrária, Recife, v. 7, suplemento, p. 784-789, 2012.

NIELSEN, K. L.; ESHEL, A.; LYNCH, J. P. The effect of phosphorus availability on the carbon economy of contrasting common bean (Phaseolus vulgaris L.) genotypes. Journal for Experimental Biology, Cambridge, v. 52, n. 3, p. 329-339, 2001.

NOGUEIRA, R. J. M. C.; ALBUQUERQUE, M. B. de.; SILVA JUNIOR, J. F. Efeito do substrato na emergência, crescimento e comportamento estomático em plântulas de mangabeira. Revista Brasileira de Fruticultura, Jaboticabal, v. 25, n. 1, p. $15-18,2003$.

NOVAIS, R. F.; SMYTH, T. J. Fósforo em solos e planta em condições tropicais. Viçosa, MG: UFV, 1999. $399 \mathrm{p}$

PAULA, Y. C. M. et al. Doses de sulfato de potássio na produção de porta-enxerto de tamarindeiro (Tamarindus indica L.). Revista Brasileira de Ciências Agrárias, Recife, v. 2, n. 5, p. 71-79, 2010.

PEREIRA, P. C. et al. A cultura do tamarindeiro (Tamarindus indica L.). 2007. Disponível em: $<$ http://www.fruticultura.iciag.ufu.br/ tamarindo.htm>. Acesso em: 23 jan. 2014.

PEREIRA, P. C. et al. Mudas de tamarindeiro produzidas em diferentes níveis de matéria orgânica adicionada ao substrato. Revista Verde de Agroecologia e Desenvolvimento Sustentável, Pombal, v. 5, n. 3, p. 152-159, 2010.

PRADO, R. M.; VALE, D. W.; ROMUALDO, L. M. Fósforo na nutrição e produção de mudas de maracujazeiro. Acta Scientarum. Agronomy, Maringá, v. 27, n. 3, p. 493-498, 2005.

QUEIROZ, J. M de O.; Emergência de plântulas e crescimento inicial de tamarindeiro em diferentes substratos. Magistra, Cruz das Almas, v. 23, n. 4, p. 221-227, 2011.

SILVA, R. P.; PEIXOTO, J. R.; JUNQUEIRA, N. T. $\mathrm{V}$. Influência de diversos substratos no desenvolvimento de mudas de maracujazeiro azedo (Passiflora eduli Sims f. flavicarpa DEG). Revista Brasileira de Fruticultura, Jaboticabal, v. 23, n. 2, p. 377-381, 2001.

SOARES, I.; LIMA, S. C.; CRISÓSTOMO, L. A. Crescimento e composição mineral de mudas de gravioleira em resposta a doses de fósforo. Revista Ciência Agronômica, Fortaleza, v. 38, n. 4, p. 343349, 2007. 
SOUSA, H.U. et al. Nutrição de mudas de bananeira em função de substratos e doses de superfosfato simples. Ciência e Agrotecnologia, Lavras, v. 24, edição especial, p. 64-73, 2000.

SOUZA, C. A. S. et al. Crescimento de mudas de gravioleira (Anonna muricata L.) em substrato com superfosfato simples e vermicomposto. Revista Brasileira de Fruticultura, Jaboticabal, v. 25, n. 3, p. 453-456, 2003.

SOUZA, H. A. et al. Doses de nitrogênio e fósforo na formação de mudas de tamarindo. Bioscience Journal, Uberlândia, v. 23, n. 1, p. 59-64, 2007.

TEDESCO, M. J. et al. Análise de solo, plantas e outros materiais. Porto Alegre, RS: UFRGS, 1995. $173 \mathrm{p}$. 